\title{
STRUCTURAL EQUATION MODELING IN TAX COMPLIANCE
}

\author{
Şahin AKKAYA ${ }^{1}$
}

\author{
Ufuk GERGERLIOĞLU²
}

\begin{abstract}
Because the concept of tax compliance is related to the voluntary fulfillment of taxpayers' tax liabilities, it is important in terms of both taxpayers and governments. Thus, more and more scientists studying in the field of public finance have been willing to study in tax compliance. It is known that the survey method is widely used in the field surveys conducted for tax compliance. The data collected in these studies based on the questionnaire method were mostly subjected to frequency analysis and parametric or nonparametric tests. In recent years, the data obtained from the field studies conducted for tax compliance have been assessed within the scope of structural equation model. As structural equation modeling is based on explanatory factor analysis and confirmatory factor analysis, it is qualified to be a stronger and more reliable statistical method. In this study, it is aimed to deal with the various aspects of structural equation modeling which is important in terms of reaching more reliable results from the data collected via questionnaire method and hence getting better guide for the policy makers. In this regard, the studies which were conducted for Turkish taxpayers' tax compliance and especially the ones regarding the structural equation modeling in the issue have been taken into consideration. Finally, in the light of previous studies on the issue, all the stages needed for the successful results in regard of the structural equation model are rigorously elaborated. Thus, it is possible to claim that this study may make a modest contribution for more reliable results leading the researchers to use a structural equation modeling.
\end{abstract}

Keywords: Tax Compliance, Confirmatory Factor Analysis, Explanatory Factor Analysis, Structural Equation Modeling

JEL Code: H26, H29

\section{Introduction}

The tax compliance of taxpayers can be defined as a concept regarding whether taxpayers fulfill their tax duties fully.Therefore, many academicians studying in the field of public finance want to conduct a field survey in the framework of tax compliance.

When it is examined the studies regarding tax compliance from the perspective of Turkey, it is seen that a lot of field research under different headings have been conducted since nearly a quarter-century. It is known that these field studies are mostly applied based on surveys. However, in these studies, it is seen that the collected data are mostly analyzed by means of the frequency analyzes and the parametric or the non-parametric tests (Saruç, 2015: 75-89).

The survey studies regarding Turkey within the context of tax compliance have particularly started to be conducted from the point of structural equation modeling in recent year. The structural equation model allows to the analysis of the survey data within the framework of a model based on the hypotheses developed after stronger tests. In this context, this study which

\footnotetext{
1 Prof., Istanbul University, Faculty of Economics, Department of Public Finance, akkays@istanbul.edu.tr

2 Assoc. Prof., Hitit University, Faculty of Economics and Administration, Department of Public Finance, ufukgergerlioglu@hitit.edu.tr
} 
is based on structural equation modeling aims to help the scientists who will conduct research concerning tax compliance.

\section{Methods Used in the Studies Regarding Tax Compliance of the Taxpayers}

Under this heading, the conceptual framework for tax compliance and the methodology used in tax compliance studies are explained.

\subsection{Conceptual Framework For Tax Compliance}

The concept of tax compliance which means the complete fulfillment of tax liabilities (Yurdadoğ et al., 2016: 806) is related to both tax evasion behaviors (Saruç, 2015, 30-31) and tax avoidance tendencies (Didinmez, 2018: 10). In addition, it is seen that the tax compliance phenomenon is discussed within the framework of the fiscal and non-fiscal purposes of the taxation (Biberoğlu, 2006: 128-129).It is also known that tax compliance is related to many factors. These factors can ranked in the form of tax audit, administrative fines, tax rates, the using of tax expenditures, tax information, participation in decision processes, norms, justice perception, tax morale (Yurdadoğ, et al., 2016: 809-812). Therefore, theoretical and practical studies within the scope of tax compliance get attention.

\subsection{Methods Used concerning the Applied Studies Conducted Within the context of Tax Compliance}

When the applied studies within the scope of tax compliance are examined, the dividing into three main categories of the methods like the official data, experiment and questionnaire which are used in these studies draws attention. (Saruç, 2015, 71). On the other hand, the studies on based interview regarding tax compliance constitute another category (Didinmez, 2018: 94). However, when the applied studies conducted as to tax compliance both in Turkey and abroad are dealt together, although the questionnaire studies are predominant and conducted in all segments of the society, the fact that the experimental studies consist mainly of the students which are used as subjects reveals another important consideration (Saruç, 2015, 72-139).

\section{Structural Equation Modeling In Tax Compliance}

When tax compliance studies conducted in Turkey for 1993-2013 years has examined, it is seen that the data of survey have mostly been analyzed by means of frequency analysis, parametric or non-parametric tests (Saruç, 2015: 75-89). The discussed topic gains important in terms of this. But, in recent years, the field surveys conducted for Turkey has been started to be evaluated in the framework of structural equation modeling. Thanks to this differentiation, the expressions of the attitude directed to the participants through the survey are tested in the framework of a model by being used implicit (latent) variables. Thus, tax compliance studies based on questionnaire are explained through hypotheses supposed within the scope of a model. Under this heading, firstly, the tax compliance studies implemented concerning the structural equation modeling and conducted regarding Turkey are discussed. After that, the conceptual framework for structural equation modeling and the method to be followed for the establishment of this model are explained. 


\subsection{Structural Equation Modeling Practices For Turkish Taxpayers' Tax Compliance}

The data which are made from the questionnaires in the studies concerning Turkey by Yeniçeri \& Çevik (2014), Giray et al. (2015), Yıldırım et al. (2016), Argan \& Devos (2017), Yücedoğru \& Sarisoy (2018) have been assessed within the scope of structural equation modeling. In each study, implicit variables for the models were identified and the effects of these implicit variables on each other were revealed. Hypotheses have been formed for each effect. In this context, the models were tested through compliance tests. According to the test results, the relationships between latent (implicit) variables were considered as statistically significant and in related to the effect levels were made interpretations.

\subsection{Conceptual Framework for Structural Equality Modeling}

The structural equation modeling presents a strong and flexible view to analyze the data provided from the participants. On the other hand, it takes into account multiple relationships included complexity between observed and unobserved variables (Hershberger \& Marcoulides, 2013: 3).

Structural Equation Model provides several advantages;

-The Hypotheses can be observed easier with a visual appearance.

-The hypothesis is easily tested by means of fit indices.

-Compared to other statistical methods, it is a more adopted method (Meydan \& Şeşen, 2015: $5-6)$.

\subsection{Conceptual Framework for Structural Equality Modeling for Future Studies}

The first step in constructing the structural equation modeling is to determine the model. In the definition of the model, the causality relations between the variables that are subject to the model should be drawn as formal (Bayram, 2016: 52).

The variables that are subject to the model are latent variables. Hypotheses are developed depending on the causal relationships between latent structures. On the basis of hypotheses, the relation of latent variables with each other should be indicated by arrows (Civelek, 2018: 47).

The literature related the structural equation model defines the latent variables as factors, dimensions or structures. In addition, it qualifies the observed variables as expressions or items directed to participants (Bowen \& Guo, 2012: 17).

One of the first analyzes in regard to being tested the structural equation model after collecting data is explanatory factor analysis (Civelek, 2018: 32-33). Measurement of the structure subject to latent variables is made through explanatory factor analysis and during this analysis are benefited from the observed variables (Bektaş, 2017: 41).

In order to apply the explanatory factor analysis, the number of the participant should reach at least fivefold level of the observed variables in the data set (Aksu et al., 2017: 8). According to the result of the analysis made in $\mathrm{SPSS}^{3}, \mathrm{KMO}^{4}$ value should be greater than 0.6 and the result

\footnotetext{
3 Statistical Package for the Social Sciences

4 Kaiser-Mayer-Olkin
} 
of the Barlet test should be significant $(P<0.05)$ (İslamoğlu \& Alnıaçık, 2014: 403). However, each factor load subject to the factor rotation application should be greater than 0.3 . Thus, it is reached to conclusion that the factors are related (Özdamar, 2017: 155-156). At the same time, the reliability analysis of the factors or the dimensions (latent structure) that contain different expressions should be done for each the factor or the dimension. As a result of these analyzes, the Cronbach's Alpha value for each dimension or factor which is greater than 0.70 indicates that there are internal consistencies of the factors or the dimensions (Bektaş \& Ulutürk Akman, 2013: 128-129).

The structures generated by explanatory factor analysis are controlled by means of confirmatory factor analysis. (Özdamar, 2017: 229). Confirmatory factor analysis helps to determine how data fit within the model can be done. In addition, confirmatory factor analysis is one of the methods that allow the testing of models and equations. Confirmatory factor analysis is also considered as a concept which is included in structural equation modeling (Child, 2006: 108).

The results of the test revealed by means of confirmatory factor analysis is correlated the fit scales. However, these fit scales should be within the range of good fit values. In particular, good fit values for five fit scales (CMIN / DF, CFI, AGFI, GFI, RMSEA) are important (Civelek, 2018: 18-19). The results of the Chi-Square Goodness of Fit or General Model Fit test (CMIN / DF) should be less than 3. This test reveals data-model fit. The Values regarding other fit tests are as follows; Comparative Fit Index (CFI) /higher than 0.95, Adjustment Goodness of Fit Index (AGFI) / higher than 0.90, the Goodness of Fit Index (GFI) / higher than 0.85. In addition to these, the index value related to the Root Mean Square Error of Approximation (RMSEA) should be less than 0.08 . The good fit values of the fit indices reveal that the model is compatible with the data (Meydan \& Şeşen, 2015: 31-36). These tests can be done through programs like AMOS, EQS, LISREL etc. (Özdamar, 2017: 185).

The test results of the confirmatory factor analysis based on the fit scales indicate whether or not the structural equation model should be tested. If the fit indices for the confirmatory factor analysis does not contain the expected values, it is not important to test the structural equation modeling (Civelek, 2018: 32-33). The structural equation model is tested as in the confirmatory factor analysis (Özdamar, 2017: 245). Within the scope of structural equation modeling, good fit values regarding fit indices (CMIN / DF, CFI, AGFI, GFI, RMSEA) are important (Bayram, 2016: 74-80). The most significant difference between testing the confirmatory factor analysis and testing the structural equation model is that in the structural equation model, the effect between the latent variables is revealed as one-way within the scope of causality relationship. On the other hand, in confirmatory factor analysis, tests are applied based on the assumption that there is a mutual relation between latent variables, regardless of causality relationship (Schreiber et al., 2006: 324-326).

\section{Conclusion}

In recent years, the survey data regarding Turkey related tax compliance have been started to be assessed within the scope of structural equation modeling which is accepted as safer method. In the meantime, it is thought that these studies will rapidly increase in the future. On the other hand, the concept of structural equation modeling has been dealing both in the form of detailed applications and in the context of intensive content theoretical knowledge in statistics books. Therefore, the issue of how to adapt the structural equation model to the field 
studies for tax compliance has important.In light of all this information, it can be said that this study will make a modest contribution for those who would like to evaluate the survey data regarding tax compliance within the scope of structural equation model.

The process of implementation of the structural equation model is as follows; the establishment of the model and creation of the hypotheses, the fictionalization of the items in scale, the implementation of the explanatory factor analysis for the data provided with of the survey method, the testing of the fit indices within the context of confirmatory factor analysis by taking into account the results of the explanatory factor analysis, the testing of the fit indices within the scope of structural equation modeling according to the results of fit test for confirmatory factor analysis, the reaching to conclusion of whether the model is compatible with the data regarding to the results of the test, the interpretation of the level of effect between the latent variables within the model if the results are consistent with the data.

\section{References}

Aksu, G., Eser, M. T. \& Güzeller, C.O. (2017) . Açımlayııı ve Doğrulayıcı Faktör Analizi ile Yapısal Eşitlik Modeli Uygulaması, Ankara, Detay Yayıncılık.

Argan, M. \& Devos, K. (2017). "Factors that Influence Tax Evasion in Australia and Turkey: A Structural Equation Model Study", ATTA Conference Papers, UNSW Business School.

Bayram, N. (2016). Yapısal Eşitlik Modellemesine Giriş, Bursa, Ezgi Kitabevi.

Bektaş, H. (2017). Açıklayıcı Faktör Analizi, İstanbul, Beta.

Bektaş, H. (2013). "Yüksek Öğretimde Hizmet Kalitesi Ölçeği: Güvenilirlik ve Geçerlilik Analizi", Ekonometri ve Istatistik, 18, ss. 116-133.

Biberoğlu, E. (2006). "Türkiye'de Gönüllü Vergi Uyumu”, (Yayımlanmamış Yüksek Lisans Tezi), İzmir, Dokuz Eylül Üniversitesi Sosyal Bilimler Enstitüsü.

Bowen, N.K. \& Guo, S. (2013). Sturctural Equation Modeling, USA, Oxford University Press.

Child, D. (2006). The Essentials of Factor Analysis, 3. Edition, USA, Continuum.

Civelek, M. E. (2018). Yapısal Eşitlik Modellemesinin Metodolojisi, İstanbul, Beta.

Didinmez, í. (2018). Davranışsal iktisat Perspektifinden Vergi Uyum Analizi, Ankara, Savaş Yayınevi.

Giray, F., Gerçek, A. \& Aydoğdu, C. (2015). “Factors Determining Taxpayers' Perception Towards Tax Fairness: The Structural Equation Model For Turkey", International Journal of Economics and Finance Studies, 7 (1), ss. 17-38.

Hershberger, S. L. \& Marcoulides, G. A. (2013). The Problem of Equivalent Structural Models, 3-39, Structural Equation Modeling: A Second Course, Editors: G. R. Hancock, R. O. Mueller.

Meydan, C. H. \& Şeşen, H. (2015). Yapısal Eşitlik Modellemesi Amos Uygulamaları, Ankara, Detay Yayıncılık.

Özdamar, K. (2017). Eğitim, Sağlık ve Davranış Bilimlerinde Ölçek ve Test Geliştirme Yapısal Eşitlik Modellemesi, Eskişehir, Nisan Kitabevi. 
Saruç, N. T. (2015). Vergi Uyumu, 2. Baskı, Ankara, Seçkin Yayıncılık.

Schreiber, J. B., Stage, F. K., King, J., Nora, A. \& Barlow, E.A. (2006). “Reporting Structural Equation Modeling and Confirmatory Factor Analysis Results: A Review", The Journal of Educational Research, 99(6), pp. 323-337.

Yeniçeri, H. \& Çevik, S. (2014). "Sosyal ve Politik Etkileşim, Bireysel Değerler ve Vergi Ahlakı Arasındaki îlişkilerin Yapısal Eşitlik Modeli ile Test Edilmesi”, Amme Idaresi Dergisi, 47(3), pp. 69-90.

Yıldırım, Z., Tansöker, R.L., Bayram, N. \& Aydemir, M. (2016). "A Structural Equation Modeling the Role of Social Norms in Tax Compliance: A Study from Turkey", International Journal of Humanities and Social Science Invention, 5 (12), ss. 81-89.

Yurdadoğ, V., Gökbunar, R. \& Tunçay, B. (2016). “Vergi Uyumunu Etkileyen Faktörlere Genel Bir Bakış", Yönetim ve Ekonomi, 23 (3), ss. 805-816.

Yücedoğru, R. \& Sarisoy İ. (2018). "Is Tax Amnesties Good for Us All? Understanding Influence of Tax Amnesties on Between Benefiters and Non-Benefiters", Cesifo, Economic Studies Conference, Munich, 2-3 November 2018. 